\title{
アルカリ沈殿法とオゾン酸化沈殿法による オゾン分解用酸化マンガン触媒の調製
}

\author{
笹岡英司 \\ 岡山県立大学保健福祉学部 栄養学科 ${ }^{+1}$ \\ 兼島昌司・阪田祐作 \\ 岡山大学工学部 精密応用化学科 ${ }^{+1+}$ \\ 仲辻忠夫 \\ 堺化学工業秼 中央研究所 ${ }^{++t+1}$ \\ 笠岡成光
}

岡山大学 地域共同研究センター

オゾン分解用 $\mathrm{Mn}_{2} \mathrm{O}_{3}$ 触媒の触媒調製条件の活性に及ぼす影響を明らかにするために $\mathrm{Mn}$ $\left(\mathrm{NO}_{3}\right)_{2}, \mathrm{MnCl}_{2}, \mathrm{MnSO}_{4}$ を原料塩として用い, アルカリ $\left(\mathrm{NaOH}, \mathrm{KOH}, \mathrm{Na}_{2} \mathrm{CO}_{3}, \mathrm{NH}_{3}\right)$ と才 ゾンを用いて種々の条件下で $\mathrm{Mn}_{2} \mathrm{O}_{3}$ 触媒を調製した。 調製した触媒の活性（オゾン分解 率：X)は，流通式充填層反応装置で測定した，入口ガスは主に $\mathrm{O}_{3}(235 \mathrm{ppm}), \mathrm{O}_{2}(18.2 \%)$, $\mathrm{H}_{2} \mathrm{O}(2.35 \%), \mathrm{N}_{2}$ (バランスガス) の混合ガスを用いた。測定結果はオゾン分解速度がオゾ ン濃度の一次として扱えることを確認し, 表面積あたりの速度定数 $\boldsymbol{k}$ を求めて, 触媒表面 活性の指標とした. また, 充塡触媒の表面積 $\left(\boldsymbol{S}_{v}\right)$ を試料触媒の比表面積と試料触媒の充填 量から求め, 触媒活性に及ぼす表面積の影響を評価した。

実験的に求めた $\boldsymbol{k}$ 值と $S_{\boldsymbol{v}}$ 值を用いて，触媒調製条件の活性に及ぼす影響を明らかにした。 また, アルカリ沈殿法とオゾン酸化沈殿法の差異を明らかにした. さらに，これらの検討 結果より，アルカリ沈殿法と同様にオゾン酸化沈殿法により高活性なオゾン分解触媒の調 製が可能であることを明らかにした。

\section{緒言}

オゾンは, 強力な酸化力を持つため殺菌剤として利用 される. 特に, 上下水道等の水処理において殺菌剤とし て塩素を用いるとトリハロメタンが生成するため, 近年 塩素のかわりにオゾンを用いる傾向にある．また，触媒 との併用によって悪臭物質の酸化剂としての利用も広が

$† 1995$ 年 3 月 14 日受理：化学工学会第 58 年会（鹿児島, 1993 年 3 月）にて発表

† テ 719-11 岡山県総社市窪木 111

††† 700 岡山市津島中 $3-1-1$

$\dagger+\uparrow \uparrow 590$ 大阪府堺市戎島町 $5-1$

†t+t† ₹ 701-12 岡山市芳賀 5302
っている.これらのオゾン利用においては未利用オゾン の処理が必要となる. 他方, 複写機, レーザープリン 夕一等の放電を利用する各種事務機器から放出されるオ ゾンは室内污染物質となるため除去が必要である。これ らの未反応オゾンの分解には主に触媒が用いられている. 触媒としては各種の金属酸化物及び貴金属が検討されて きたが，実用触媒には酸化マンガン（二酸化マンガン） が多く利用されているようである（Nakatuji, 1992； Yoshimoto et al., 1989).

本研究では, アルカリ沈殿法とオゾン酸化沈殿法の 2 種の調製法により $\mathrm{Mn}_{2} \mathrm{O}_{3}$ を調製し, 調製法の活性・安 定性に及ぼす影響を明らかにした。 さらに，これらの検 討結果より，オゾン酸化沈殿法により高活性な触媒が調 
製できることを明らかにした。 なお，オゾン酸化沈殿法 については古くから廃水処理の 1 方法として知られてお り (“Yousui Haisui Binran”, 1973), また電極材料と しての $\mathrm{MnO}_{2}$ の調製法としてあ既に検討されているが (Nishimura et al., 1992; Nishimura et al., 1992), 触媒 調製法としての検討例は少ないようである.

\section{1. 実 験 法}

\section{$1 \cdot 1$ 触媒調製}

アルカリ沈殿は, 次のようにして行った. $\mathrm{Mn}_{2} \mathrm{O}_{3}$ と して, $18.2 \mathrm{~g}$ に相当するマンガン塩（主に硝酸塩，一部 塩化物，硫酸塩）を含む金属塩水溶液（主に $10 \mathrm{wt} \%$ ） をイオン交換水を用いて調製した。 他方, 沈殿剂水溶液 としては主に $\mathrm{Na} / \mathrm{Mn}$ 比 4.4 （量論量の $120 \%$ 過剩）の $\mathrm{NaOH}$ を含む水溶液（主に $\mathrm{NaOH}$ として $7 \mathrm{wt} \%$ 水溶 液）を調製した。なお，沈殿剤は $\mathrm{Na} / \mathrm{Mn}$ 比 4.4 以外に $3.8,2.7,2.2,1.8,1.4,1.0,0.5$ でも検討した。 さらに, 沈殿剂は $\mathrm{NaOH}$ 以外に $\mathrm{NH}_{3}, \mathrm{KOH}, \mathrm{Na}_{2} \mathrm{CO}_{3}$ も用いた。 沈殿は，沈殿剂水溶液に金属塩水溶液を強靦汼下瞬時に 注入する方法によって行った．沈殿温度は主に室温（約 $298 \mathrm{~K})$ で一部は沈殿温度を变化（280〜 363 K）させ 行った.このようにして得られた沈殿物は水洗（デカン テーションを繰り返す), ろ過, 乾燥 (空気中, $383 \mathrm{~K}$, $25 \mathrm{~h}$ ), 焼成（精製空気流中, 所定温度, $3 \mathrm{~h}$ ), 破砕し, 平均粒径 $0.5 \mathrm{~mm}(-28 /+35$ meshes $)$ に篩い分け, 触媒試料として使用した。

オゾン酸化沈殿法は，例えば $\mathrm{Mn}\left(\mathrm{NO}_{3}\right)_{2}$ を塩の 1 例 にすると，沈殿反応は以下のように表すことができる.

$\mathrm{Mn}\left(\mathrm{NO}_{3}\right)_{2}+\mathrm{H}_{2} \mathrm{O}+\mathrm{O}_{3} \rightarrow \mathrm{MnO}_{2}+\mathrm{O}_{2}+2 \mathrm{HNO}_{3}$

実際には, 所定濃度のマンガン塩水溶液(主に硝酸塩)を $400 \mathrm{~g}$ 調製し,この溶液を $1 \mathrm{dm}^{3}$ の丸底フラスコに入れ, 約 $3 \%$ のオゾンを含む $\mathrm{O}_{3}-\mathrm{O}_{2}$ 混合ガスを $80 \mathrm{~cm}^{3} / \mathrm{min}, \mathrm{NTP}$ 40時間, 内径 $4 \mathrm{~mm}$ のテフロン製チューブでフラスコの底 部に注入した.このようにして得た沈殿物は水洗, 万過, 乾燥 $(383 \mathrm{~K}, 25 \mathrm{~h})$ 後, 主に $823 \mathrm{~K} て ゙ 3$ 時間精製空気流中焼成, 平均粒径 $0.5 \mathrm{~mm}$ に篩い分けて触媒として用いた。 なお, $383 \mathrm{~K}$ 乾燥物は $\mathrm{MnO}_{2}$ に近いの状態にあり, 乾燥物も一部 触媒として用いた。

触媒の比表面積は $\mathrm{N}_{2}$ 吸着, BET 法（島津製作所製, ADS-1 B ) で，触媒の XRD は X 線回折装置（島津製 作所製， $\mathrm{XD}-3 \mathrm{~A}, \mathrm{CuK} \alpha$ ) で測定した。触媒の酸素脱 離特性は, 定速昇温脱離装置を用いて測定した。

\section{$1 \cdot 2$ オソンン分解実験}

実験装置は，常圧流通式・充填層反応装置（反応管は 硬質ガラス製の内径 $3.4 \mathrm{~mm}$ のもの, 主に触媒 $0.03 \mathrm{~cm}^{3}$ 充填）を用いた，反応管は 2 重管の内管になっており，

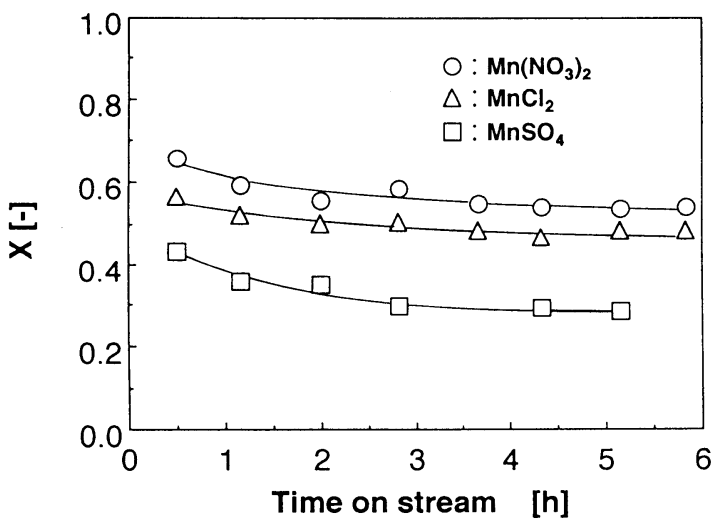

Fig. 1 Activity of $\mathrm{Mn}_{2} \mathrm{O}_{3}$ prepared by alkali precipitaion. Precipitant : $\mathrm{NaOH}, C_{s}: 10$ wt \%, $C_{p r}: 7$ wt \%, molar ratio of $\mathrm{Na} / \mathrm{Mn}: 4.4, T_{p r}: 298 \mathrm{~K}, T_{c}: 823 \mathrm{~K}$. Reaction condition : $S V: 3.2 \times 10^{5} \mathrm{~h}^{-1}$

外管は内径 $20 \mathrm{~mm}$ のガラス管で所定温度の温水を循環 させ反応温度を $303 \mathrm{~K}$ に保った。，入口ガスは，主に $\mathrm{O}_{3}$ (235 ppm), $\mathrm{O}_{2}$ (18.2\%), $\mathrm{H}_{2} \mathrm{O}(2.35 \%), \mathrm{N}_{2}$ (バラン ス）の混合ガス $\left(160 \mathrm{~cm}^{3} / \mathrm{min}, \mathrm{NTP}\right)$ を用いた. 空間 速度 $(S V)$ は, 主に $3.2 \times 10^{5} \mathrm{~h}^{-1}$ で行った。 入口・出 ロガス中の $\mathrm{O}_{3}$ 濃度は, 湿式吸収法であるヨウ素滴定法 （JISK 0103）で測定した.

\section{2. 実験結果ならびに考察}

\section{$2 \cdot 1$ 調製した $\mathrm{Mn}_{2} \mathrm{O}_{3}$ の活性評価}

Fig. 1 に, 原料塩として硝酸塩, 塩化物, 硫酸塩を 用い, 沈殿剂として $\mathrm{NaOH}(\mathrm{Na} / \mathrm{Mn}$ 比 4.4）を用いて アルカリ沈殿法により調製した $\mathrm{Mn}_{2} \mathrm{O}_{3}$ （823 K 焼成）の $\mathrm{O}_{3}$ 分解に対する活性の経時安定性の検討結果を示した. 縦軸の $\mathrm{O}_{3}$ 分解率 $X$ は, 次式で算出した.

$$
X=\frac{\left(\text { 入口 } \mathrm{O}_{3} \text { 濃度 }\right)-\left(\text { 出口 } \mathrm{O}_{3} \text { 濃度 }\right)}{\left(入 口 \mathrm{O}_{3} \text { 濃度 }\right)}
$$

検討した 3 種の塩の内では硝酸塩を用いた $\mathrm{Mn}_{2} \mathrm{O}_{3}$ の 活性が最む高く, 経時安定性については 3 者について有 意な差は認められなかった. Fig. 2 は硝酸マンガンを 原料塩とし，沈殿剂の影響を検討した結果である. 沈殿 剤としては， $\mathrm{NaOH}$ が適していると言える，以上， マ ンガン原料塩と沈殿剤の影響を明らかにしたが, 各触媒 の充填容積を統一しているため, 当然各実験における充 填触媒の表面積が異なる。したがって, 正確な原料塩 種・沈殿剂種の影響を知るためには表面積の差違を補正 する必要がある．そこで，表面積当たりの活性の評価を 検討した。

$\mathrm{O}_{3}$ の接触分解を一次反応之仮定すると, 充填層反応 装置は管型流通式反応器として取り扱えることから, 次 


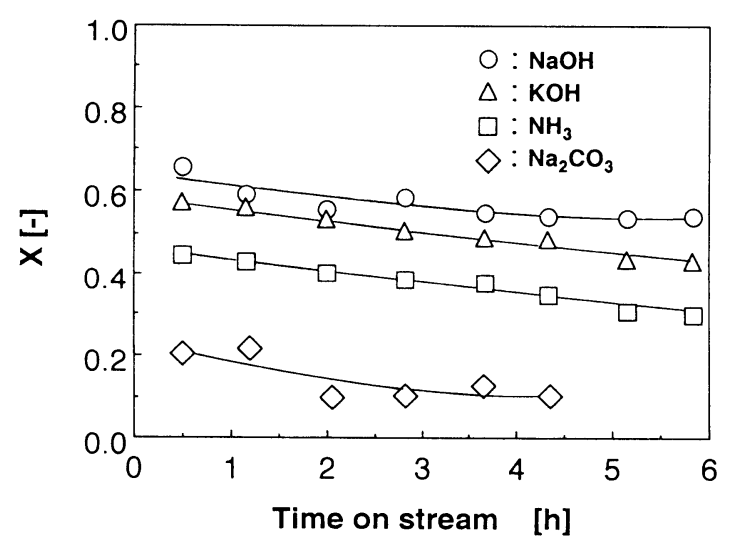

Fig. 2 Effect of precipitant kind on activity of $\mathrm{Mn}_{2} \mathrm{O}_{3}$ prepared by alkali precipitaion. Raw salt : Mn $\left(\mathrm{NO}_{3}\right)_{2}, C_{s}: 10 \mathrm{wt} \%, C_{p r}: 7 \mathrm{wt} \%$, molar ratio of $\left(\mathrm{Na}, \mathrm{K}\right.$ or $\mathrm{NH}_{3}$ ) /Mn : 4.4, $T_{p r}: 298 \mathrm{~K}, T_{c}: 823 \mathrm{~K}$. Reaction condition : $S V: 3.2 \times 10^{5} \mathrm{~h}^{-1}$

式から一次反応の速度定数 $k$ を求めることができる.

$$
\begin{aligned}
& k=-\left(G_{d} / S_{v}\right) \ln (1-X) \\
& G_{o}=F_{d} / C_{o}
\end{aligned}
$$

ここで， $F_{0}$ はオゾン供給速度， $C_{o}$ は入口ガス中の $\mathrm{O}_{3}$ 濃 度， $G_{0}$ は入口ガス供給速度である． $S_{v}$ は充填された試 料触媒の表面積を表し, 次式で求められる.

$$
S_{v}=S_{g} W_{g}
$$

ここで， $S_{g}$ は触媒の比表面積, $W_{g}$ は触媒充塡重量であ る.

さて， $\mathrm{O}_{3}$ の分解反応が一次で Eq. (2) が本反応系に 適用できるかを検討した，検討には硝酸マンガンを原料 塩として用い，沈殿剤として $\mathrm{NaOH}(\mathrm{Na} / \mathrm{Mn}$ 比 4.4) と $\mathrm{Na}_{2} \mathrm{CO}_{3}(\mathrm{Na} / \mathrm{Mn}$ 比 2.2）を用いて調製した（823 K 焼成）触媒を用いた。実験は，まず硝酸塩 $-\mathrm{NaOH}$ 試料 を用い，触媒充塡量（空間速度）を变化させることによ り検討した。 その結果, Fig. 3 に示したように Eq. （2）の関係を満足していることが知られた。 しかし, 物質移動過程の影響のおそれが考えられる。 そこで，本 実験では触媒の比表面積・表面状態が同一で粒子当たり の表面積のみが異なる触媒試料を用いて検討した。 すな わち, 触媒を圧縮成形し触媒充填容積（空間速度）を同 一にした場合， $S_{v}$ 值が $41 \%$ 増加する試料を調製し， $S_{v}$ 対 $X$ の関係を検討した. その結果, Fig. 3 にあわせて 示したように他のデータとほぼ同一の $k$ 值が得られた。 さらに, 入口 $\mathrm{O}_{3}$ 濃度をそれまでの $1 / 2$ に変化させた 場合もほぼ同一の $k$ 值が得られた。 これらの検討結果, 特に圧縮成型した触媒試料について非圧縮の試料とほぼ 同一の $k$ 值が得られたことから, 物質移動過程の影響 は大きくないとして，Eq.（2）から表面積当たりの活

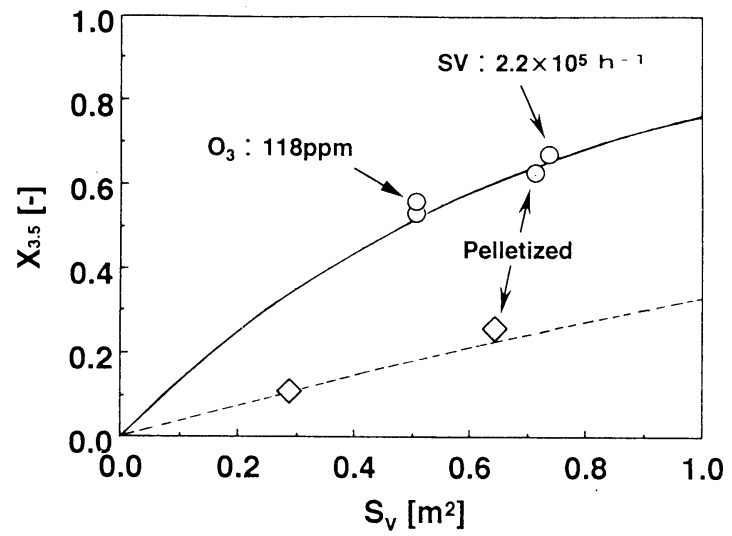

Fig. 3 Relationship between conversion of $\mathrm{O}_{3}, X$ and total surface area of catalyst sample, $S_{v}$

Sample $1: \mathrm{Mn}_{2} \mathrm{O}_{3}$ prepared by alkali precipitaion using $\mathrm{Mn}\left(\mathrm{NO}_{3}\right)_{2}$ (10 wt $\%$ aq.) and $\mathrm{NaOH} \mathrm{(} 7 \mathrm{wt}$ $\%$ aq., Na/Mn : 4.4), $T_{p r}: 298 \mathrm{~K}, T_{c}: 823 \mathrm{~K}$. Sample $2: \mathrm{Mn}_{2} \mathrm{O}_{3}$ prepared by alkali presipitaion using $\mathrm{Mn}\left(\mathrm{NO}_{3}\right)_{2}$ (10 wt\% aq.) and $\mathrm{Na}_{2} \mathrm{CO}_{3}$ ( $7 \mathrm{wt} \%$ aq., $\mathrm{Na} / \mathrm{Mn}: 2.2), T_{p r}: 298 \mathrm{~K}$. Two samples were used after pelletized in order to increase $S_{v}$ Reaction conditions; $S_{V}: 3.2 \times 10^{5} \mathrm{~h}^{-1}$ or $2.2 \times 10^{5} \mathrm{~h}^{-1}$, inlet concentration of $\mathrm{O}_{3}: 235 \mathrm{ppm}$ or $118 \mathrm{ppm}$. Solid and broken lines are obtained from equation (2) using $k, 3.9 \times 10^{-4} \mathrm{~cm} \mathrm{~s}^{-1}$ for sample 1 , and $1.16 \times 10^{-4} \mathrm{~cm} \mathrm{~s}^{-1}$ for sample 2 , respectively.

性 $k$ を評価することにした。 なお，Fig. 3 では反応開 始後 3.5 時間におけるデータ $X_{3.5}$ を用いた. これは反応 開始直後は反応系の非定常性からデー夕の精度に問題が あるためで, その後の測定時間の中間点の値を用いるこ とにした. Fig. 3 の結果より 2 種の触媒の $k$ 值は $3.9 \times$ $10^{-4}$ と $1.1 \times 10^{-4} \mathrm{~cm} \mathrm{~s}^{-1}$ とそれぞれ評価され, 両者の 表面積当たりの活性が約 3 倍異なることが知られた。

\section{$2 \cdot 2$ アルカリ沈殿法における調製方法の活性に与え る影䠗}

まず，原料塩の影響については Fig. 1 の結果より $X_{3.5}, k$ 值が求まる. その結果を $S_{g}, S_{v}$ 值とあわせて Table 1 に示した. すなわち原料塩種による $S_{v}$ 值の差 異が $k$ 值の差異より小さいことから, 見かけの活性 $X_{3.5}$ に対しては表面活性 $k$ の差異の影響が支配的といえ る.この表面活性の差異は調製時に残留されるとされる 陰イオンが触媒表面に存在し, 後述の表面酸素に影響を 及ぼしている可能性がある.

沈殿物の乾燥後の焼成温度の影響について, 硝酸マン ガン（10 wt\%）より調製した乾燥物を用いて検討した. その結果, Fig. 4 に示したように $S_{8} S_{v}$ 值は焼成温度の 上昇に伴って焼結により減少するが, $k$ 值は極大值が存 在し, 結果的に $X_{3.5}$ 值に極大が存在する事が知られた. 
Table 1 Effects of raw salt and precipitant on $k, S_{\mathfrak{w}} S g$ and $X_{3.5}$

\begin{tabular}{|c|c|c|c|c|c|}
\hline & & $\begin{array}{l}X_{3.5} \\
{[--]}\end{array}$ & $\begin{array}{c}S_{g} \\
{\left[\mathrm{~m}^{2} \mathrm{~g}^{-1}\right]}\end{array}$ & $\begin{array}{c}S_{v} \\
{\left[\mathrm{~m}^{2}\right]}\end{array}$ & $\begin{array}{r}k \times 10^{4} \\
{\left[\mathrm{~cm} \mathrm{~s}^{-1}\right]}\end{array}$ \\
\hline \multirow{3}{*}{ Raw salt ${ }^{a)}$} & $\mathrm{Mn}\left(\mathrm{NO}_{3}\right)_{2}$ & 0.53 & 21 & 0.51 & 4.0 \\
\hline & $\mathrm{MnCl}_{2}$ & 0.49 & 21 & 0.51 & 3.6 \\
\hline & $\mathrm{MnSO}_{4}$ & 0.29 & 22 & 0.45 & 2.0 \\
\hline \multirow{4}{*}{ Precipitant $t^{\mathrm{b}}$} & $\mathrm{NaOH}$ & 0.53 & 21 & 0.51 & 4.0 \\
\hline & $\mathrm{KOH}$ & 0.49 & 21 & 0.50 & 3.6 \\
\hline & $\mathrm{NH}_{3}$ & 0.38 & 16 & 0.38 & 3.3 \\
\hline & $\mathrm{Na}_{2} \mathrm{CO}_{3}$ & 0.09 & 15 & 0.29 & 0.9 \\
\hline
\end{tabular}

a) conditions : same in Fig. 1,

b) conditions : same in Fig. 2

極大值存在の理由については後述するが，焼成温度が高 く, 焼結が進行した場合, 触媒表面の安定化が進行し活 性が低下すると推測される.

沈殿剤種の影響について硝酸マンガン（10 wt\%）を 用い，沈殿剂濃度を $120 \%$ 過剩の条件下 $\left(\mathrm{Na}, \mathrm{K}, \mathrm{NH}_{3} /\right.$ $\mathrm{Mn}=4.4$ ） で検討した. その結果, Table 1 に併示し たように $k$ 值の序列は沈殿剤種によって $\mathrm{NaOH}>\mathrm{KOH}$ $>\mathrm{MH}_{3} \gg \mathrm{Na}_{2} \mathrm{CO}_{3}$ となった。 $X_{3.5}$ 值は $S_{v}$ 值と $k$ 值によっ て決まるが， $\mathrm{Na}_{2} \mathrm{CO}_{3}$ の場合は他の三者に比較して特に $k$ 值が小さく,$X_{3.5}$ 值の差異の主要因は $k$ 值の差による あのであることが知られた。この原因としては前述の原 料塩の場合之同様に残留炭酸イオンの影響が考えられる が，原因解明のためにはさらに検討が必要である.

沈殿剂濃度の影響については, $\mathrm{Mn}\left(\mathrm{NO}_{3}\right)_{2}-\mathrm{NaOH}$ 系 で $\mathrm{Na} / \mathrm{Mn}$ 比を種々変化させて検討した。 その結果,

Fig. 5 に示すように $S_{v} S_{g}$ の両值は沈殿剂量が量論比付 近で極小值を示すのに対し， $k$ 值は $\mathrm{Na} / \mathrm{Mn}$ モル比の増 加に伴って増加し, 量論比付近以上ではほぼ一定值を示 すことが知られた． $\mathrm{NaOH}$ 過剩側では， $k$ と $S_{v}$ の值か ら沈殿条件としては $\mathrm{Na} / \mathrm{Mn}$ 比 4 付近以上が適している といえる。 他方, $\mathrm{NaOH}$ 量が量論值より不足側でも, $\mathrm{NaOH}$ 量が少なくなるほど $k$ 值の低下以上に $S_{8} S_{v}$ 值 は大きくなる傾向にあり，その結果， $X_{3.5}$ が大きくなっ た. $\mathrm{NaOH}$ 量が不足の領域における $S_{v}$ 值の変化の原因 は，次に述べる生成沈殿物濃度と関連しているようであ る.なお，共沈後の $\mathrm{pH}$ は水溶液にイオン交換水を加え $5 \mathrm{dm}^{3}$ にした後測定したが $\mathrm{Na}$ 過剩側では $\mathrm{pH} 13$ でほぼ 一定値を示し, $\mathrm{NaOH}$ 不足側では $\mathrm{pH} 7$ 付近の一定值を 示した.

$\mathrm{Mn}\left(\mathrm{NO}_{3}\right)_{2}-\mathrm{NaOH}$ 系 で $\mathrm{Na} / \mathrm{Mn}$ モル比を 4.4 と一定 にし, 沈殿剤と金属塩水溶液濃度を同時に变化させて水 溶液濃度の影響を検討した。 その結果，Fig. 6 に横軸

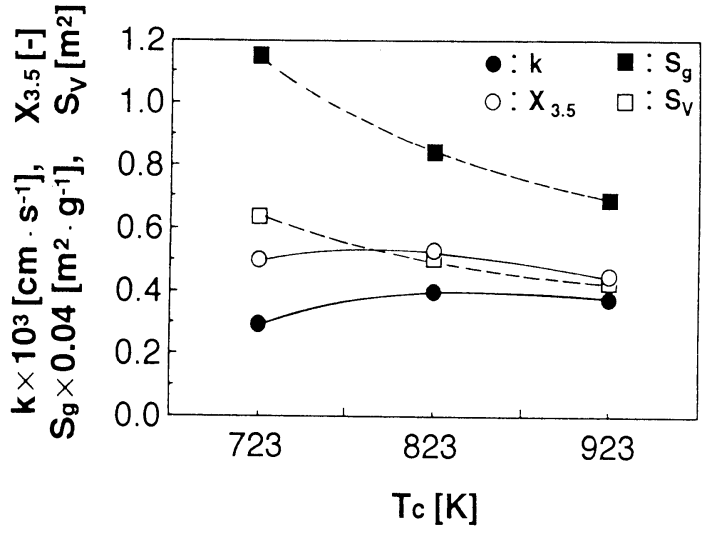

Fig. 4 Effect of calcination temperature on $k, S_{v}, S_{g}$ and $X_{3.5}$

Raw salt: $\mathrm{Mn}\left(\mathrm{NO}_{3}\right)_{2}, C_{s}: 10 \mathrm{wt} \%, C_{p r}: 7 \mathrm{wt} \%$, molar ratio of $\mathrm{Na} / \mathrm{Mn}: 4.4, T_{p r}: 298 \mathrm{~K}$. Reaction conditions : inlet concentration of $\mathrm{O}_{3}: 235 \mathrm{ppm}$, $S V: 3.2 \times 10^{5} \mathrm{~h}^{-1}$

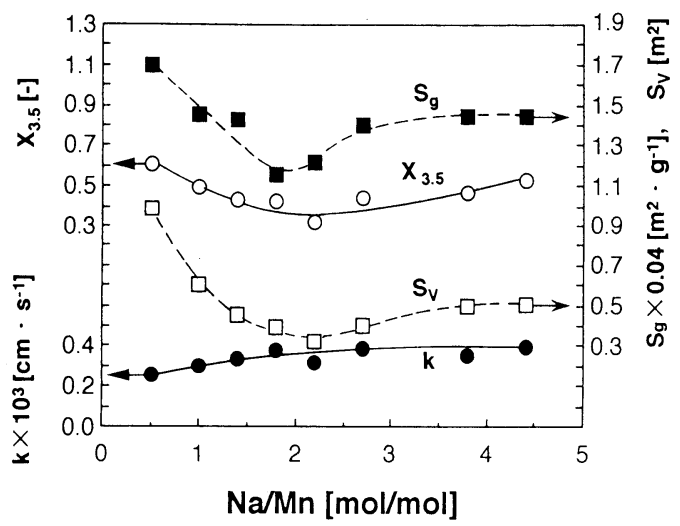

Fig. 5 Effect of molar ratio of $\mathrm{Na} / \mathrm{Mn}$ on $X_{3.5}, S_{v}, S_{8}$ and $k$.

Raw salt : $\mathrm{Mn}\left(\mathrm{NO}_{3}\right)_{2}, C_{s}: 10 \mathrm{wt} \%$, Precipitant : $\mathrm{NaOH}, T_{p r}: 298 \mathrm{~K}, T_{c}: 823 \mathrm{~K}$. Reaction conditions : inlet concentration of $\mathrm{O}_{3}: 235 \mathrm{ppm}, \mathrm{SV}: 3.2$ $\times 10^{5} \mathrm{~h}^{-1}$

を $\mathrm{Mn}\left(\mathrm{NO}_{3}\right)_{2}$ 濃度 $C_{s}[w t \%]$ にして示したように $X_{3.5}$ は $\mathrm{Mn}\left(\mathrm{NO}_{3}\right)_{2}$ 濃度 3〜5 $\mathrm{wt} \%$ でほぼ一定值を示し，そ れ以上濃度が増大すると低下の傾向を示した。他方， $k$ 值はこれまで（金属塩水溶液 $10 \mathrm{wt} \%$ ）の条件で極大值 を示し， $S_{v}$ 值は濃度の減少に伴って明確に増大した。 これらの検討結果より, $X$ 值の変化は大部分が $S_{v}$ 值の 寄与によるものであることが知られた．以上， $X_{3.5}$ の值 からは水溶液濃度を $5 \mathrm{wt} \%$ 付近が適していること, $k$ 值は $10 \mathrm{wt} \%$ 付近で最大となることが知られた。

沈殿温度の影響については, $\mathrm{Mn}\left(\mathrm{NO}_{3}\right)_{2}-\mathrm{NaOH}$ 系で $\mathrm{Na} / \mathrm{Mn}$ 比 4.4（金属塩水溶液 $10 \mathrm{wt} \%$ ）の条件で検討し 


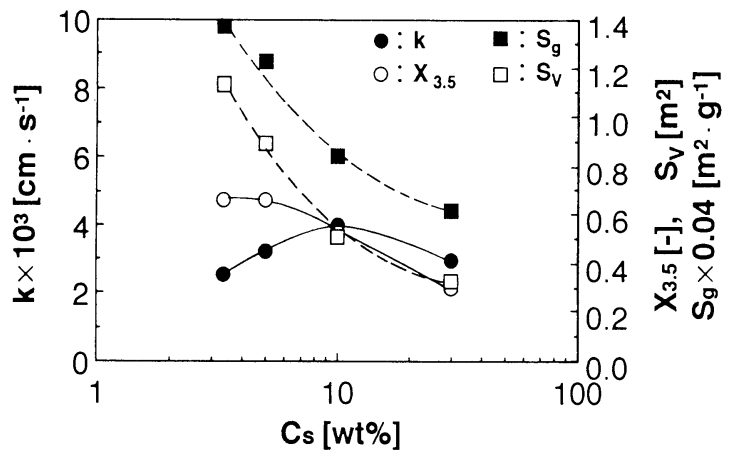

Fig. 6 Effect of concentration of salt on $X_{3.5}, S_{t}, S_{8}$ and $k$. Raw salt : $\mathrm{Mn}\left(\mathrm{NO}_{3}\right)_{2}$. Precipitant: $\mathrm{NaOH}$, molar ratio of $\mathrm{Na} / \mathrm{Mn}: 4.4, T_{p r}: 298 \mathrm{~K}, T_{c}: 823 \mathrm{~K}$. Reaction conditions : inlet concentration of $\mathrm{O}_{3}: 235$ ppm, $S \dot{V}: 3.2 \times 10^{5} \mathrm{~h}^{-1}$

た. その結果， Fig. 7 に示したように $X_{3.5}$ 值は室温付 近で大きくなり，それ以上に温度の上昇させると $X_{3.5}$ 值は低下する傾向を示した。 この主な原因は， $S_{8}$ 值の 低下に伴う $S_{v}$ 值の低下にあり, $k$ 值の温度に対する変 化は小さいと言える。

以上，アルカリ沈殿法について触媒調製条件が $X, k$, $S_{v}$ 值に及ぼす影響を検討し，さらに $X$ が触媒表面活性 と表面積のどちらの因子の影響をより大きく受けている かを明らかにした。 また，上記の検討結果より明らかに なった望ましい具体的調製条件は以下のようになる。 (1) 原料塩として硝酸塩を用い，沈殿剂としては $\mathrm{Na}_{2} \mathrm{CO}_{3}$ の 使用を避けること，(2)焼成温度は $823 \mathrm{~K}$ 付近が適して いること，(3)アルカリは $\mathrm{Na} / \mathrm{Mn}$ 比 4 付近以上の過剩が 適していること，(4)沈殿温度は室温近傍が適しているこ と等を明らかにした。

\section{3 オゾン酸化沈殿法における調製条件の活性に 及ぼす影豐}

オゾン酸化沈殿では原料塩として硝酸塩，塩化物と硫 酸塩を用いた。 オゾン酸化沈殿法では $\mathrm{MnO}_{2}$ が得られ るとされ (Nishimura et al., 1992; Nishimura et al., 1992), $\mathrm{MnO}_{2}$ は $\mathrm{O}_{3}$ 分解に対し活性を持っとされている (Nakatuji，1992），そこで，まず，金属塩水溶液濃度 $3.3 \mathrm{wt} \%$ 用い，沈殿温度 ca. $287 \mathrm{~K} （ \pm 1 \mathrm{~K})$ の場合の 乾燥沈殿物の触媒活性を検討した。その結果，いずれの 乾燥物む $\mathrm{O}_{3}$ 分解に対し活性を持つこと $(X$ は約 0.5$)$ が確認された．なお，アルカリ沈殿法の場合の乾燥物の デー夕は前項では割愛したが，硝酸塩（10wt\% aq）$\mathrm{NaOH}(\mathrm{Na} / \mathrm{Mn}$ 比 4.4) 系における乾燥物の $X$ は 0.18 であった。乾燥物を $823 \mathrm{~K}$ で焼成し，得られた $\mathrm{Mn}_{2} \mathrm{O}_{3}$ （XRD で確認）の触媒活性・安定性は，Fig. 8 に示し たように原料塩種による差異は認められなかった。また，

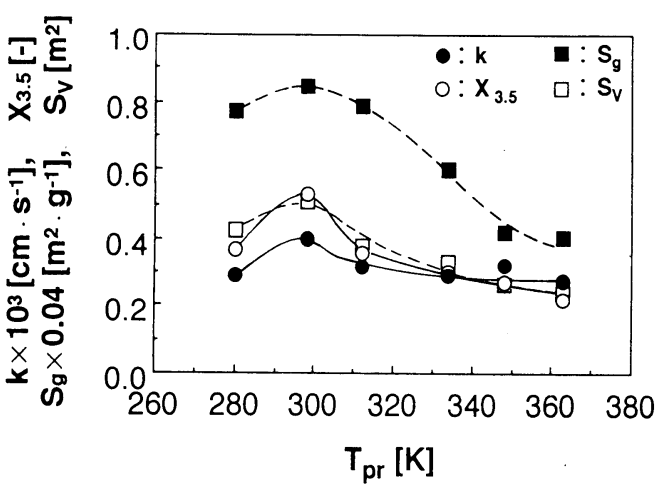

Fig. 7 Effect of temperature of precipitation on $X_{3.5} S_{w}$ $S_{\mathrm{g}}$ and $k$.

Raw salt : $\mathrm{Mn}\left(\mathrm{NO}_{3}\right)_{2}, C_{s}: 10 \mathrm{wt} \%$. Precipitant : $\mathrm{NaOH}, C_{p r}: 7$ wt $\%$, molar ratio of $\mathrm{Na} / \mathrm{Mn}: 4.4$ Reaction conditions : inlet concentration of $\mathrm{O}_{3}$ : $235 \mathrm{ppm}, \mathrm{SV}: 3.2 \times 10^{5} \mathrm{~h}^{-1}$

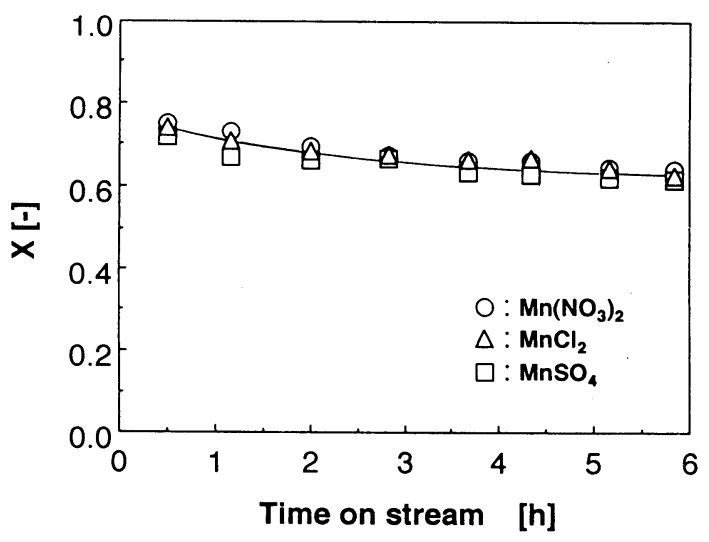

Fig. 8 Activity of $\mathrm{Mn}_{2} \mathrm{O}_{3}$ prepared by ozone precipitation. $C_{s}: 3.3 \mathrm{wt} \%, T_{p r}: 287 \mathrm{~K}, T_{c}: 823 \mathrm{~K}$. Reaction conditions : inlet concentration of $\mathrm{O}_{3}: 235 \mathrm{ppm}$, $S V: 3.2 \times 10^{5} \mathrm{~h}^{-1}$

$S_{g}$ 值， $S_{v}$ 值， $k$ 值にも有為な差は認められず， アルカ リ沈殿法の場合とは異なり，原料塩の影響が無視できる ことが知られた。

焼成温度の影響については，硝酸マンガンから調製し た試料を用いた。 その結果， Fig. 9に示したように $X$ 值から見ると $773 \sim 823 \mathrm{~K}$ の焼成温度が適しているこ とが知られた，さらに，923 K の高温焼成では $k$ 值の低 下よりあ $S_{v}$ 值の低下（シンタリングによる $S_{8}$ の低下に よる）が活性の低下に大きく寄与していること， $k$ 值は 焼成温度が $723 \mathrm{~K}$ から $773 \mathrm{~K}$ になると顕著に増大する ことが知られた。 これらの焼成温度の影響はアルカリ沈 殿法の場合（Fig. 4 参照）之類似しているといえる.

硝酸塩水溶液（3.3 wt\%）を用い，オゾン酸化沈殿時 の温度を $278 \sim 298 \mathrm{~K}$ （沈殿時間内の温度变化は約 \pm 1 


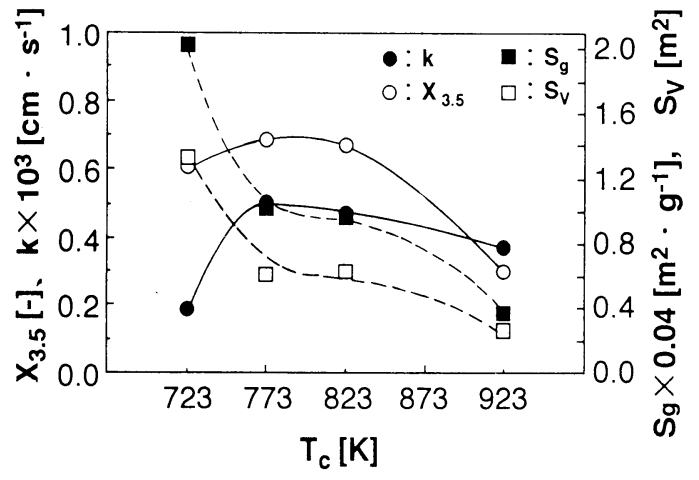

Fig. 9 Effect of calcination temperature on $k, S_{v}, S_{8}$ and $X_{3.5}$

Raw salt $: \mathrm{Mn}\left(\mathrm{NO}_{3}\right)_{2}, C_{s}: 3.3 \mathrm{wt} \%$. Precipitant : $\mathrm{O}_{3} . \quad T_{p r}: 287 \mathrm{~K}$. Reaction conditions : inlet concentration of $\mathrm{O}_{3}: 235 \mathrm{ppm}, \mathrm{SV}: 3.2 \times 10^{5} \mathrm{~h}^{-1}$

K）変化させ, 沈殿温度の影響を検討した。 その結果, 沈殿温度の活性に及ぼす影響は小さいと判断できた (デー夕割愛).

金属塩水溶液濃度の影響については硝酸塩を用い，沈 殿温度は $285 \mathrm{~K}$ で検討した. その結果, Fig. 10 に示し たようにデータのばらつきが大きいが， $k$ 值は $1 \sim 10$ $\mathrm{wt} \%$ 範囲内ではほぼ一定のようである． $S_{w} \quad S_{g}$ は 10 wt\%以下の範用では, アルカリ沈殿法と同様に濃度が 低下するに従って大きくなる傾向か認められた.

以上，オゾン酸化沈殿法の場合の調製条件として混合 条件（ガスー水溶液）は一定と考えて, 沈殿時の温度,

濃度を制御したが, 混合の制御面で不十分の点があるよ うで, 今後の課題を残した. しかし, オゾン酸化沈殿法 とアルカリ沈殿法との差異をある程度明らかにできた。

また，アルカリ沈殿法で調製した触媒と同等以上の $k$ 值を持つ高活性な触媒の調製がオゾン酸化沈殿法で可能 であることも明らかにした。

\section{$\mathbf{2 \cdot 5}$ 調製触媒のキャラクタリゼーション}

調製した $\mathrm{Mn}_{2} \mathrm{O}_{3}$ 触媒 (823 K 焼成) の XRD を測定し た結果, 一例を Fig. 11 に示したようにアルカリ沈殿法, オゾン酸化沈殿法で調製したいずれの触媒も $\mathrm{Mn}_{2} \mathrm{O}_{3}$ の みが同定された。

調製触媒の活性酸素の特性を定速昇温脱離法（TPD） で検討した（Kasaoka and Sasaoka, 1988). まず，焼 成温度の影響（Fig. 4, Fig. 9）を検討した試料につ いて測定した。 その結果, アルカリ沈殿法の場合の結果 をFig. 12 に示したように，焼成温度が高くなると焼成 時に酸素を取り込み $\mathrm{Mn}_{2} \mathrm{O}_{3}$ に変化してゆく事が確認で きた.アルカリ沈殿法では， 2 価の原料塩を用いている ため生成物は $\mathrm{Mn}(\mathrm{OH})_{2}$ と考えられる. 沈殿, 乾燥時

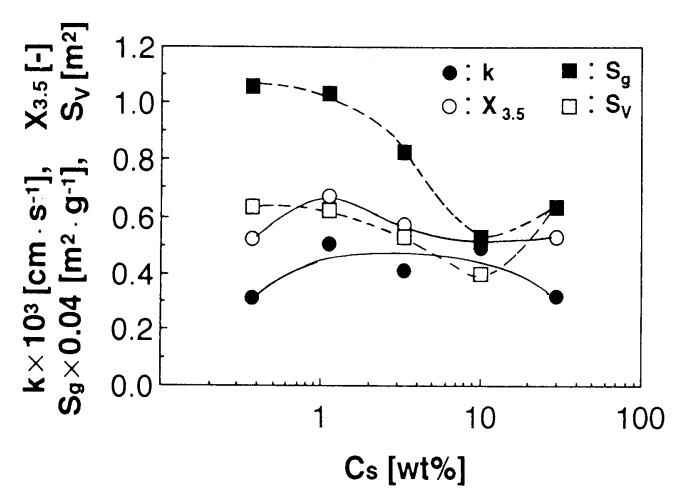

Fig. 10 Effect of concentration of salt on $X_{35} S_{b}, S_{g}$ and $k$. Raw salt: $\mathrm{Mn}\left(\mathrm{NO}_{3}\right)_{2}$. Precipitant: $\mathrm{O}_{3}, T_{p r}: 285 \mathrm{~K}$, $T_{c}: 823 \mathrm{~K}$. Reaction conditions : inlet concentration of $\mathrm{O}_{3}: 235 \mathrm{ppm}, \mathrm{SV}: 3.2 \times 10^{5} \mathrm{~h}^{-1}$

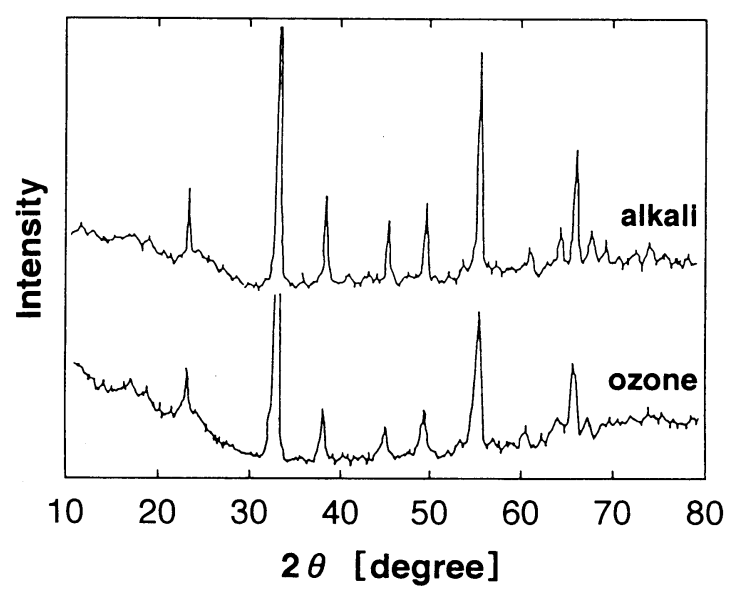

Fig. 11 XRD patterns of samples prepared by alkali and ozone precipitation.

Sample A : $\mathrm{Mn}_{2} \mathrm{O}_{3}$ prepared by alkali precipitation using $\mathrm{Mn}\left(\mathrm{NO}_{3}\right)_{2}, C_{s}: 10 \mathrm{wt} \%$ and $\mathrm{NaOH}, C_{p r}: 7 \mathrm{wt}$ $\%(\mathrm{Na} / \mathrm{Mn}: 4.4), T_{p r}: 298 \mathrm{~K}, T_{c}: 823 \mathrm{~K}$.

Sample B : $\mathrm{Mn}_{2} \mathrm{O}_{3}$ prepared by ozone precipitation using $\mathrm{Mn}\left(\mathrm{NO}_{3}\right)_{2}, C_{s}: 3.3 \mathrm{wt} \%, T_{p r}: 287 \mathrm{~K}, T_{c}: 823$ K.

に空気と接触するため一部酸素を取り込む（酸化され る）が，焼成前は大部分が 2 価の状態にある. したがっ て, 上記の結果は空気中焼成時に酸化が進行し酸素を取 り込んだことを示していると言える， $k$ 值の焼成温度依 存性と Fig. 12 の結果が対応していることから，酸素の 取り込みによって活性サイトが生成している可能性があ る. なお, $923 \mathrm{~K}$ 付近からの酸素の脱離は $\mathrm{Mn}_{2} \mathrm{O}_{3}$ が $\mathrm{Mn}_{3} \mathrm{O}_{4}$ に分解するのに伴って放出される酸素である （TPD 後のサンプルが $\mathrm{Mn}_{3} \mathrm{O}_{4}$ になっていることを XRD で確認し，また酸素脱離量が $\mathrm{Mn}_{2} \mathrm{O}_{3} \rightarrow \mathrm{Mn}_{3} \mathrm{O}_{4}$ に対応す ることも確認した)。オゾン酸化沈殿法の場合は，Fig. 


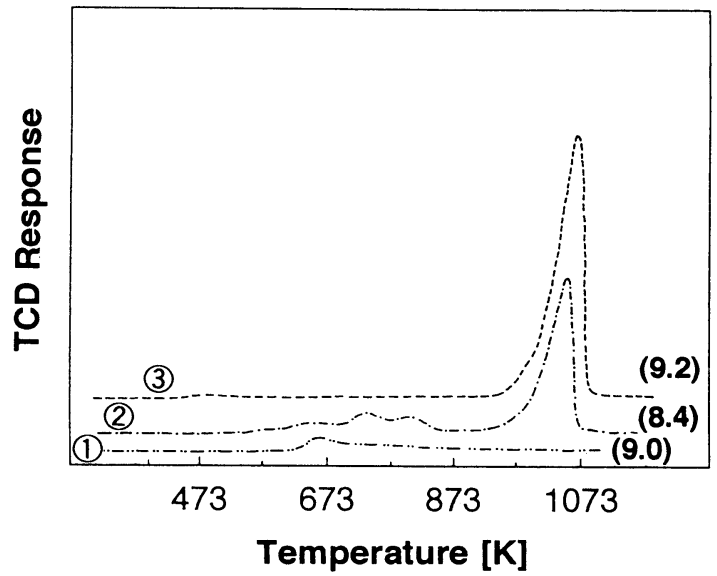

Fig. 12 Effect of calcination temperature of sample prepared by alkali precipitation on its TPD profile. Preparation conditions: $\mathrm{Mn}\left(\mathrm{NO}_{3}\right)_{2}, C_{s}: 10 \mathrm{wt} \%$; $\mathrm{NaOH}(\mathrm{Na} / \mathrm{Mn}: 4.4), C_{p r}: 7 \mathrm{wt} \%, T_{p r}: 298 \mathrm{~K}$. Samples $1: 383 \mathrm{~K}, 25 \mathrm{~h}$ dry. $2: 723 \mathrm{~K}, 3 \mathrm{~h}$ after dry. $3: 823 \mathrm{~K}, 3 \mathrm{~h}$ after dry. TPD conditions $: 10$ $\mathrm{K} \min ^{-1}$. ( ) : sample weight $[\mathrm{mg}]$

13 に示したように焼成によって酸素を脱離し $773 \mathrm{~K}$ 以 上の焼成物は $\mathrm{Mn}_{2} \mathrm{O}_{3}$ になっている。 なお，乾燥物の組 成は脱離酸素量から, $\mathrm{MnO}_{1.95}$ に, $873 \mathrm{~K}$ 以下で脱離する 酸素は $\mathrm{MnO}_{1.95} \rightarrow \mathrm{Mn}_{2} \mathrm{O}_{3}$ に対応する。この $\mathrm{MnO}_{1.95} \rightarrow$ $\mathrm{Mn}_{2} \mathrm{O}_{3}$ の变化之前述の $773 \mathrm{~K}$ 付近での $k$ 值が増加 (Fig. 9) が対応していることから，脱酸素過程で活性 サイトが生成している可能性がある.

以上，両沈殿法に打ける乾燥物の焼成による特性変化 を検討した結果，焼成により $\mathrm{Mn}_{2} \mathrm{O}_{3}$ が得られる温度付 近で $k$ 值が最大となることが知られた．焼成時の酸素 が付加される過程，あるいは酸素が脱離する過程で触媒 表面が不安定な状態になっていると推測されることから， 活性サイトが生じやすいと考えると実験結果を説明する ことができる.

さて， Fig. 12， Fig.13の $823 \mathrm{~K}$ 焼成物の TPD にお いて $473 \mathrm{~K}$ 付近の低温で少量の酸素の脱離が認められ た。 そこでこの低温部での酸素の脱離と活性の関係を知 るため，溶液濃度を变化させた場合の $823 \mathrm{~K}$ 焼成物の TPD を試料量をふやして測定した。 その結果，TPDの 低温部分を拡大すると $503 \mathrm{~K}$ 付近に酸素の脱離ピーク が存在し, 溶液濃度によって若干ピークに差が認められ た. しかし， 活性 $k$ との相関は認められなかった。 ア ルカリ沈殿法の場合むほぼ同一低温温度域にピークが認 められたが, この場合も $k$ 值との相関は認められな かった.

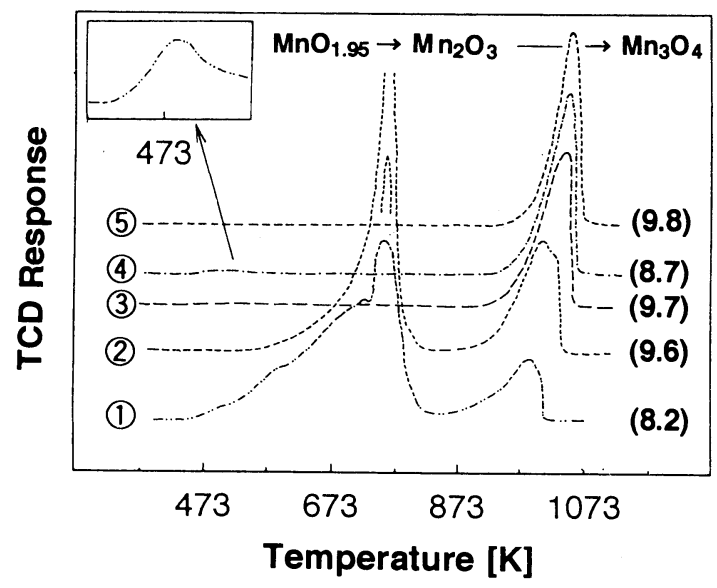

Fig. 13 Effect of calcination temperature on TPD profile of sample prepared by ozone precipitation.

Preparation conditions: $\mathrm{Mn}\left(\mathrm{NO}_{3}\right)_{2}, C_{s}: 3.3 \mathrm{wt} \%$, $T_{p r}: 287 \mathrm{~K}$. Samples $1: 383 \mathrm{~K}, 25 \mathrm{~h}$ drying. $2: 723 \mathrm{~K}$, $3 \mathrm{~h}$ after drying. $3: 773 \mathrm{~K}$, after drying, $4: 823 \mathrm{~K}, 3 \mathrm{~h}$ after drying, $5: 923 \mathrm{~K}$ after drying. TPD conditions: $10 \mathrm{~K} \mathrm{~min}^{-1}$. ( ) : sample weight $[\mathrm{mg}]$.

\section{$2 \cdot 6$ オゾン分解に伴う表面酸素の蓄積}

$\mathrm{MnO}_{2}$ 系オゾン分解触媒においてはオゾン分解によっ て生成した酸素の脱離速度が遅いために触媒表面に残留 し，活性の低下をあたらすとされている（Nakatuji， 1992; Yoshimoto et al., 1989). そこで，オゾン酸化沈 殿法で得られた $\mathrm{MnO}_{2}$ 系触媒 $\left[\mathrm{Mn}\left(\mathrm{NO}_{3}\right)_{2}, \quad 3.3 \mathrm{wt} \%\right.$ 水 溶液, $383 \mathrm{~K}$ 乾燥物] のオン゙ン分解に使用した直後の試 料の TPD スペクトルを測定した。 その結果, Fig. 14 に示したように $373 \mathrm{~K}$ 付近に新たなピークが認められ, 触媒上に酸素が蓄積されることが確認された。 さらに, そのピーク位置が $\mathrm{MnO}_{2}$ の分解に起因する酸素の脱離 よりあ低温側に存在する.

$\mathrm{Mn}_{2} \mathrm{O}_{3}$ 触媒に場合についても，代表触媒として上記 の乾燥物の $823 \mathrm{~K}$ 焼成物とアルカリ沈殿法（10 wt\% $\mathrm{Mn}\left(\mathrm{NO}_{3}\right)_{2}$ 水溶液, $\mathrm{Na} / \mathrm{Mn}$ 比 4.4, $823 \mathrm{~K}$ 焼成物) で調 製した触媒を用いて検討した。 その結果，Fig. 15 に示 したように $\mathrm{MnO}_{2}$ 系触媒の場合とほぼ同一の温度域に 蓄積酸素の脱離によると思われるピークが認められた。 ピーク面積は，オゾン酸化法により調製した触媒の方が アルカリ沈殿法によって調製した触媒に比へて約 2 倍程 度大きい.これは両触媒の比表面積の比が約 2 であるこ とに対応しており, 此表面積当たりの酸素蓄積量はほぼ 同程度であると言える.

以上の検討結果より, 触媒の調製法が異なっても, ま た $\mathrm{MnO}_{2}$ 系と $\mathrm{Mn}_{2} \mathrm{O}_{3}$ 系とで触媒のバルクの組成が異 なっても蓄積される酸素種は同一種と予測された。この 


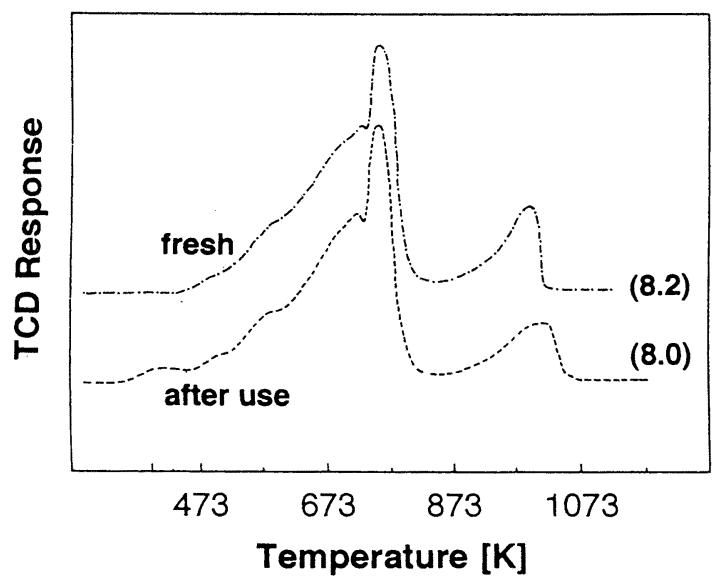

Fig. 14 Oxygen accumulation on the $\mathrm{MnO}_{2}$ sample prepared by ozone precipitation during ozone decomposition-TPD profiles-

Preparation conditions: $\mathrm{Mn}\left(\mathrm{NO}_{3}\right)_{2}, C_{s}: 3.3 \mathrm{wt} \%$, $T_{p r}: 287 \mathrm{~K}, 383 \mathrm{~K}$ dry. Reaction conditions : inlet concentration of $\mathrm{O}_{3}: 235 \mathrm{ppm}$, space velocity : 3 . $2 \times 10^{5} \mathrm{~h}^{-1}$. TPD conditions : $10 \mathrm{~K} \mathrm{~min}^{-1}$. ( ): sample weight $[\mathrm{mg}]$.

結果のみではこれらの触媒における活性サイト種が同一 であると判断できないが，類似している可能性があると 言える. 今後はさらに, 表面分析を進め活性サイトの同 定を進める必要がある.

以上，上記の検討によっても $k$ 值が変化する原因に ついては解明できなかった点が多い，今後, この $k$ 值 の变化の原因が解明できると, 高活性触媒の調製が可能 になる.

\section{結言}

オゾン分解用触媒開発の基礎研究として $\mathrm{Mn}_{2} \mathrm{O}_{3}$ 触媒 を取り上げ, 触媒調製法として従来のアルカリ沈殿法と オゾンー酸素混合ガスを用いるオゾン酸化沈殿法を用い, 触媒の調製条件の活性に及ぼす影響を検討した，活性は， 見かけの反応速度に及ぼす触媒の比表面積と表面積当た りの活性の影響を分離して評価した。すなわち，(1)比表 面積に関しては充媜した触媒重量に比表面積を乗じた試 料表面積で評価し，(2)表面積当たりの活性は，オゾン分 解速度がオゾン濃度の一次に依存するとして速度定数を 求めて評価した。これらの試料表面積と速度定数の評価 を行うことによって，アルカリ沈殿法とオゾン酸化沈殿 法について原料塩（アルカリ沈殿の場合は沈殿剂も含 め), 沈殿条件，焼成条件の活性に及ぼす影響をかなり 明らかにした。ささらに定速昇温脱離法により，アルカリ 沈殿法及びオゾン分解法によって調製した $\mathrm{Mn}_{2} \mathrm{O}_{3}$ は調 製法は異なるが表面状態は類似していることを明らかに

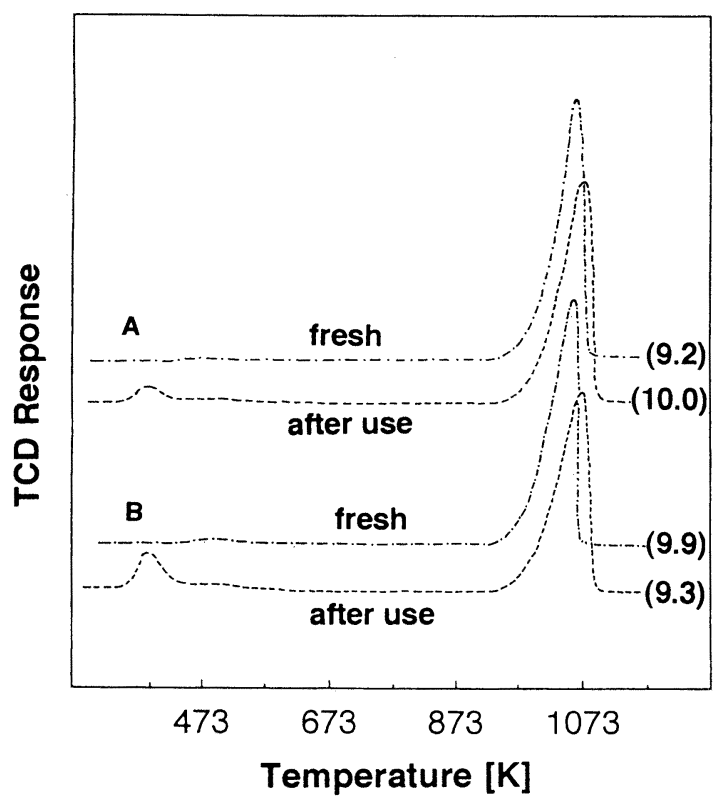

Fig. 15 Oxygen accumulation on the $\mathrm{Mn}_{2} \mathrm{O}_{3}$ sample prepared by alkali precipitaion or ozone precipitation during ozone decomposition-TPD profiles-

Preparation conditions: $\mathrm{Mn}\left(\mathrm{NO}_{3}\right)_{2}, \mathrm{C}_{s}: 10 \mathrm{wt} \%$, $\mathrm{NaOH}(\mathrm{Na} / \mathrm{Mn}: 4.4), C_{p r}: 7 \mathrm{wt} \%, T_{p r}: 298 \mathrm{~K}$, $T_{c}: 823 \mathrm{~K}$. Reaction conditions : inlet concentration of $\mathrm{O}_{3}: 235 \mathrm{ppm}$, space velocity $: 3.2 \times 10^{5} \mathrm{~h}^{-1}$. TPD conditions $: 10 \mathrm{~K} \mathrm{~min}^{-1}$. ( ): sample weight [mg]. A : alkali precipitaion, B : ozone precipitation

した.これらの検討によって，オゾン酸化沈殿法によっ て高活性マンガン触媒の調製が可能なことを明らかにし た. 今後は $\mathrm{k}$ 值を低下させることなく $, S_{g}, S_{v}$ 值を増加 させる手法を開発する必要がある.

\section{Nomenclature}

$C_{o}=$ inlet concentration of $\mathrm{O}_{3} \quad\left[\mathrm{~mol} \mathrm{~cm}{ }^{-3}\right.$, NTP $]$

$C_{s}=$ concentration of salt in aqueous solution

$C_{p r}=$ concentration of precipitant

[wt\%]

$F_{o}=$ feed rate of reactant

[wt\%]

$G_{o}=$ feed rate of inlet gas

$\left[\mathrm{cmol} \mathrm{s}^{-1}\right]$

$k=$ rate constant $\left[\mathrm{cm}^{3} \mathrm{~s}^{-1}, \mathrm{NTP}\right]$

$S_{g} \quad=$ specific surface area of catalyst $\left[\mathrm{cm} \mathrm{s}^{-1}\right]$

$S_{v}=$ total surface area of catalyst charged in the reactor

$S V=$ space velocity

$T_{p r}=$ precipitation temperature

$T_{c}$ = calcination temperature 


\section{$W_{p}=$ amount of catalyst charged in the reactor \\ $X=$ conversion of $\mathrm{O}_{3}$ to $\mathrm{O}_{2}$ \\ $X_{3.5}=$ conversion of $\mathrm{O}_{3}$ at $3.5 \mathrm{~h}$ from start \\ $[-]$ \\ Literature cited \\ Kasaoka, S and E. Sasaoka : Shokubai, 30, 44-47 (1988) \\ Nakatuji, T : Shokubai, 34, 241 - 244 (1992) Gakkaishi, 108,473-477 (1992) Gakkaishi, 108, $891-895$ (1992) Nagasaki, 3 C 29, p 178-179 (1989) (1973). \\ Preparation of Manganese Oxide Catalysts for Decomposition of Ozone by Alkali and Ozone Precipitation Methods}

Nishimura, T., T. Kamaya and Y. Umetsu : Shigen Sozai

Nishimura, T., Y. Umetsu and M. Sasaki : Shigen Sozai

Yoshimoto, M., T. Nakatuji and K.Nagano: Preprints of the Annual Meeting of Catalysis Society of Japan,

“Yousui Haisui Binran", p 388, Maruzen Book Company

\author{
Eiji Sasaoka \\ Dept. of Nutritional Science, Okayama Prefectural University, Soja 719-11 \\ Shoji Kaneshima and Yusaku Sakata \\ Dept. of Appl. Chem., Okayama Univ., Okayama 700 \\ Tadao Nakatsuji \\ Sakai Chemical Ind. Co., Ltd. R\&D Div., Sakai 590 \\ Shigeaki Kasaoka \\ Cooperative Research Center, Okayama Univ., Okayama 701-12
}

Key Words: Ozone, Manganese Oxide, Catalytic Decomposition of Ozone, Alkali Precipitation, Ozone Precipitation

To clarify the effect of the preparation conditions of $\mathrm{Mn}_{2} \mathrm{O}_{3}$ catalysts on their activity for the decomposition of ozone, $\mathrm{Mn}_{2} \mathrm{O}_{3}$ catalysts were prepared from manganese salts $\left[\mathrm{Mn}\left(\mathrm{NO}_{3}\right)_{2}, \mathrm{MnCl}_{2}, \mathrm{MnSO}_{4}\right]$ using alkali $\left(\mathrm{NaOH}, \mathrm{KOH}, \mathrm{Na}_{2} \mathrm{CO}_{3}, \mathrm{NH}_{3}\right)$ and ozone $\left(\mathrm{O}_{3}-\mathrm{O}_{2}\right.$ mixed gas) under different conditions. Catalytic activities (conversion of $\mathrm{O}_{3}$ to $\mathrm{O}_{2}$ ) of the prepared samples were measured using a fixed-bed flow type reactor. The inlet gas was mainly composed of $\mathrm{O}_{3}(235 \mathrm{ppm}), \mathrm{O}_{2}(18.2 \%), \mathrm{H}_{2} \mathrm{O}(2.35 \%)$ and $\mathrm{N}_{2}$ (balance). The rate of catalytic decomposition was analyzed as a first order reaction with regard to $\mathrm{O}_{3}$ concentration, and the rate constant, $k$ thus obtained was used to evaluate the surface activity. The total surface area of the sample charged in the reactor $\left(S_{v}\right)$ was calculated from the specific surface area and weight of the sample, and used for evaluation of the effect of surface area on catalytic activity.

By evaluating $k$ and $S_{v}$, the effects of preparation conditions on the activity of the sample were clarified. Furthermore, differences between alkali precipitation and ozone precipitation methods were also clarified. From this study, it was concluded that an active catalyst for ozone decomposition could be prepared by the ozone precipitation method as well as by the alkali precipitation method. 